\title{
Küreselleşme ve Kamu Sektörü İstihdamı: Orta Gelirli Ülkeler Üzerine Bir İnceleme
}

\author{
Orhan CENGİ'1, Müge MANGA ${ }^{2}$ \\ Özet
}

Küreselleşmenin kamu sektörü büyüklüğü üzerindeki etkisi verimlilik hipotezi ve telafi hipotezi çerçevesinde ele alınmaktadır. Bu çalışmada, küreselleşmenin kamu sektörü istihdamı kanallyla kamu sektörü büyüklügüne etkisi incelenmiştir. 2000-2014 periyodu verileriyle orta gelirli 14 ülke için yapılan analiz sonuçlarına göre küreselleşme, kamu sektörü istihdamıyla negatifiliş̧kilidir. Diğer ifadeyle dışa açıklık arttıkça kamu sektörünün küçüleceğini öngören verimlilik hipotezini destekleyen bulgular elde edilmiştir. Ayrıca yapılan nedensellik testi bulguları, Bolivya, Brezilya, Honduras, Pakistan ve Peru'da küreselleșmeden kamu sektörü istihdamına doğru tek yönlü nedensellik ilișkisinin olduğunu göstermektedir.

Anahtar Kelimeler: Küreselleşme, kamu sektörü istihdamı, kamu harcamaları, verimlilik hipotezi, telafi hipotezi Jel Kodu: F66, H53, J68

\section{Globalization and Public Sector Employment: An Investigation on Middle Income Countries}

\section{Abstract}

The impact of globalization on the size of the public sector is addressed within the context of the efficiency hypothesis and compensation hypothesis. In this study, the impact of globalization on public sector size is examined through public sector employment. According to the analysis results for 14 middle-income countries by using data over the period 2000-2014, globalization is negatively associated with public sector employment. In other words, findings have been obtained supporting the efficiency hypothesis, which predicts that the public sector downsizes as openness increases. Also, causality test findings show that there exists a one-way causality relationship running from globalization to public sector employment in Bolivia, Brazil, Honduras, Pakistan, and Peru.

Keywords: Globalization, public sector employment, public expenditure, efficiency hypothesis, compensatory hypothesis Jel Codes: F66, H53, J68

\section{GİRIŞ}

Dünya çapında entegrasyon sürecini ifade eden küreselleşme, son 60 yılda yeni teknolojiler ve uzmanlaşma ile birlikte taşıma ve işlem maliyetlerini düşürerek, uluslarararası ticaretteki engellerin azalıșına eșlik etmiștir (Spence, 2011: 28). Bilgiyi, kolaylıkla ve düşük maliyetle elde etmeye ihtiyaç duyan kurumlara ve kişilere kolaylıkla aktarılabilme kapasitesi, küreselleşme çağını farklı kılmakla beraber birtakım problemleri de beraberinde getirmektedir. Küreselleşmeyle beraber, özellikle yeni teknolojilere daha kolay uyum sağlayabilen yüksek teknik yetenek ve becerilere sahip işgücünün bu durumdan olumlu etkileneceği görüşüne karşılık, teknik değişimlere uyum sağlayamayan düşük vasıflı işçilerin olumsuz etkileneceği ve böylelikle işçilerin mevcut işlerini kaybetmelerine neden olacağı ileri sürülmektedir (Tanzi, 2000: 4). Doğu Asya deneyimde görüldüğü gibi piyasa dinamiklerinin serbestleştirilmesiyle düşük tarife ve taşıma maliyetleri, her ülkeyi

ATIF ÖNERÍsi (APA): Cengiz, O., Manga, M. (2021). Küreselleșme ve Kamu Sektörü İstihdamı: Orta Gelirli Ülkeler Üzerine Bir İnceleme. İzmir İktisat Dergisi. 36(3). 517-533. Doi: 10.24988/ije.202136302

1 Öğr. Gör. Dr., Çukurova Üniversitesi, Pozantı Meslek Yüksekokulu, Muhasebe ve Vergi Bölümü, Pozantı/ADANA, EMAIL: ocengiz@cu.edu.tr ORCID: 0000-0002-1883-4754

2 Doç. Dr., Erzincan Binali Yıldırım Üniversitesi, İktisadi ve İdari Bilimler Fakültesi, İktisat Bölümü, Merkez/ERZiNCAN EMAIL: mangamuge@gmail.com ORCID: 0000-0003-2675-2182 
karşılaştırmalı üstünlüğe sahip olduğu ürünlerin üretiminde uzmanlaşmaya yönlendirerek, istihdamın artmasına yol açmaktadır. Diğer yandan daha fazla ekonomik entegrasyon, yeni teknolojilere ve organizasyon yapılarına uyum sağlamak için gerekli olan becerilere sahip olmayanları dezavantajlı duruma getirirken, işgücü arasında eşitsizliklere yol açmaktadır. Latin Amerika ve Çin'de bu durum en çok öne çıkan örnekler olmuştur. Küreselleşmenin işgücü alanında yarattığı bu olumsuzluklar "dibe çeken rekabet" ve "dijital bölünme" gibi kavramların arkasında yatan şüpheler kapsamında ele alınmaktadır (Rama, 2003: 159-160).

Davidson vd. (1999: 272)'ye göre küreselleşmenin ticaret politikası kanalıyla istihdam üzerindeki etkisinin yeterli düzeyde incelenmesi göz ardı edilmektedir. Bunun iki nedeni vardır: İlki ticaret, kaynakların dağılımına odaklanan mikro-ekonomik bir alan olarak görülürken işsizlik, iktisadi faaliyetlerin genel seviyesi ve diğer iktisadi performansla ilişkilendirilen makroekonomik bir endişe olarak görülmektedir. İkincisi ise uluslararası ticaret, ticaret politikalarının gerçek dünyadaki ekonomi politikaları üzerindeki etkisi hakkında sonuçlar çlkarmak için matematiksel modellerden hareketle açıklanmaya çalışılan mikro tabanlı teorik bir alan gibi düşünülmektedir.

Dışa açıklık kapsamında ele alınan küreselleşmenin istihdam başta olmak üzere birçok alanda meydana getirdiği riskler ve kırılganlıklar, kamusal politikaları yakından etkilemektedir. Buna göre ülkeler, uluslararası piyasalara entegre oldukça bireylerin dışsal şoklara maruz kalma riski ve işsizlik artmaktadır. $\mathrm{Bu}$ noktada kamusal kaynaklara yönelik talepler artmakta ve devlet kamu istihdamı, sosyal güvenlik ve refah harcamalarıyla ortaya çıkan bu durumu

\footnotetext{
3 Analizin yapıldığı tarih itibariyle Arjantin, Brezilya, Kolombiya, Kosta Rika, Ekvador, Paraguay, Romanya ve
}

bertaraf etmeye çalıșmaktadır (Shelton, 2007: 2231).

Küreselleşmenin, zaman içerisindeki gelişimi incelendiğinde bütün bölgeleri ve toplumun tüm katmanlarını kapsayan simetrik yapıdan ziyade asimetrik yapıya sahip olduğu görülmektedir. Küreselleşme, az gelişmiş ülkelerde tarım ve sanayi sektörünü olumsuz etkileyerek işsizliğin artmasına yol açmaktadır. Söz konusu süreçte sanayileşmiş ülkeler korumacı politikaları benimserken, az gelişmiş ülkelere serbestleşme politikalarını istikrar aracı olarak sunmaktadır. Dolayısıyla gelişmiş ve yeni sanayileşen ülke deneyimleri göz önüne alındığında devletin rolünün önemi az gelişmiş ülkeler için de ortaya çlkmaktadır (Şenses, 2010: 126-128). Buna ilave olarak küreselleşme, sermaye piyasalarını daha fazla bütünleştirerek az gelişmiş ülkelere finansman kaynağı sunsa da finansal akımların yönü ve miktarına bağlı olarak ortaya çıkan belirsizlikler, kurumsal denetimin yeterli olmadığı ülkelerde makroekonomik istikrarsızlıklara ve krizlere yol açmıștır (Şenses, 2004: 17). Örneğin, 1990'larda Washington Konsensüsü kapsamında uygulanan serbestleşme yanlısı politikaların gelişmekte olan ülkelerin çoğunda beklenilenin tersine istikrarsızlık yaratması ve benzer biçimde 2008 krizinin yaşanması, mali politikaların önemini yeniden ortaya çıkarmıştır (Karakurt, 2011: 36).

$\mathrm{Bu}$ kapsamdan yola çıkarak küreselleşme ile ortaya çıkan risklerin yaşanabileceği ülkelerden olan orta gelirli 14 ülkede küreselleşmenin kamu sektörü istihdamına etkisi incelenmiştir. Mevcut çalışmada, Dünya Bankası sınıflandırmasına göre orta gelirli ${ }^{3}$ ülkeler grubuna dâhil olan 14 ülkede Augmented Mean Group (AMG) ve Kónya bootstrap nedensellik testleri kullanılarak 2000-2014 dönemi verileriyle küreselleşmenin kamu istihdamı üzerindeki etkisi test edilmiştir. Çalışmada ilk olarak

Peru Üst Orta Gelirli ülke grubunda Bolivya, El Salvador, Honduras, Pakistan, Filipinler ve Ukrayna Alt Orta Gelirli ülke grubunda yer almaktadır. 
küreselleşmenin kamu harcamaları ve istihdamına etkisini ele alan yaklaşımlar incelenmekte, ikinci olarak ilgili literatür taramasına yer verilmektedir. Üçüncü bölümde, çalışmada kullanılan veri, model ve ampirik metodoloji ortaya konulmaktadır. Daha sonraki bölümde elde edilen bulgulara yer verilip, son bölümünde ise elde edilen bulgular dâhilinde politika önerileri tartışılmaktadır.

\section{KÜRESELLEŞMENİN KAMU İSTİHDAMINA ETKİSI}

Küreselleşmenin kamu harcamalarının bileșimine ve bununla ilişkili olarak kamu sektörü istihdamına olan etkisi verimlilik hipotezi (efficiency hypothesis) ve telafi hipotezi (compensation hypothesis) kapsaminda ele alınmaktadır.

Verimlilik hipotezi; küreselleşmenin, sermayenin artan mobilitesi nedeniyle sermaye kaçışını önlemek için hükümetlerin vergileri düşürme baskısını artırdığını ifade etmektedir. Finansal piyasaların uluslararası entegrasyonu bütçe açı̆̆ı üzerinde de baskı yaratarak kamu harcamalarının azalmasına yol açmaktadır (Busemeyer, 2009: 456). Özellikle refah amaçlı yüksek düzeyde kamu harcamaları, ülkenin küresel ölçekteki rekabet gücünü zayıflatmaktadır. Bunun nedeni, ülkedeki vergi oranlarını yükselten kamu harcamalarının ekonomiyi verimsiz hâle getirmesidir. $\mathrm{Bu}$ nedenle, küresel piyasalar daha fazla bütünleşik ve rekabete açlk hâle geldikçe işgücü, mal ve hizmet piyasalarının serbestleştirilmesi, verimsiz düzenlemelerin azaltılması, kamu işletmelerinin özelleştirilmesi, vergi oranlarının düşürülmesi ve hatta emeklilik dâhil olmak üzere diğer sosyal harcamaların azaltılması yoluyla rekabetçi olunması tavsiye edilmektedir (Tanzi, 2004: 9). Böylelikle küreselleşme sosyal refah harcamalarının maliyetini artırarak kamu harcamalarının kısılmasına neden olmaktadır (Schulze ve Ursprung, 1999: 345). Garrett (2001), verimlilik hipotezi bağlamında devletin temel harcamalar dişında yaptığı müdahalelerin yerli üreticilerin uluslararası piyasalardaki rekabet gücünü aşındırdığını belirtmektedir. Transfer programları ve sosyal hizmetler gibi müdahaleler, işgücü piyasasının işleyişini bozarak zamanlararası yatırım kararlarını olumsuz etkilemektedir. Ayrıca, kamu harcamaları genellikle kısa vadeli borçlanma ve nihayetinde daha yüksek vergilerle finanse edildiğinde ilerici verginin daha da artmasına neden olmaktadır. Borçlanma kanalı, daha yüksek reel faiz oranlarıyla sonuçlanarak yatırımları daha da baskılamaktadır. Yüksek faiz oranlarının reel döviz kurunda bir değerlenmeye yol açması halinde yerli üreticilerin rekabet gücü bu yolla da azalmaktadır (Garrett, 2001: 5-6).

Telafi hipotezi, Cameron (1978)'ın 18 gelişmiş kapitalist ülkede küreselleşmenin kamu sektörü büyüklüğü üzerindeki etkisini incelediği çalışmaya dayanmaktadır. Dışa açıklıktan kaynaklanan ekonomik, sosyal ve politik unsurlardan hareketle kamu ekonomisinin büyümesi Şekil 1'de özetlenmektedir.

Buna göre açık ekonomiler yüksek derecede sanayi yoğunlaşmasına, yani birkaç büyük firmada muazzam büyüklükte üretim ve istihdam payına sahiptir. Yüksek düzeydeki sanayi yoğunlaşması, rekabetçi olmayan az sayıdaki sektörde homojen işgücünün varlığıyla birlikte sendikaların büyümesine elverișli ortam yaratmaktadır. Göreceli olarak yüksek sendikalaşmanın varlığı da sol hükümetlerin iktidarda kalmalarının ön koşullarından biridir. Çünkü sendikalı işçiler sol partilerin tabanını oluşturmaktadır. Böylelikle dışa açıklık, sosyal alt yapının gelişimini kolaylaştırarak kamu ekonomisini genişletmektedir. Diğer ifadeyle açık ekonomilerde hükümetler, tüketimin büyük kısmını harcamalar yoluyla ulusal ekonomi üzerindeki kontrolünü genişleterek dişa bağımlığın etkilerini önlemeye çalışmaktadır (Cameron, 1978: 1257). Cameron (1978)'ın hipotezini daha geniş ülke grubu üzerinde inceleyen Rodrik (1996) ise ülkelerin dünya piyasalarıyla iç içe geçmeleri sonucu uluslararası piyasalardan kaynaklanan risklere 
daha fazla maruz kalma eğiliminde olduğunu vurgulamaktadır. $\mathrm{Bu}$ nedenle açık ekonomilerde devlet, kamu istihdamı ve diğer kamusal harcamalar yoluyla, diğer faaliyetlere özellikle ticaret sektörüne klyasla istikrar sağlayıcı işlev üstlenmektedir. Dolayısıyla, dışsal şoklardan önemli ölçüde etkilenen ülkelerde hükümet, kamusal kaynakları kullanarak riskleri azaltmaktadır (Rodrik, 1996: 13-14).

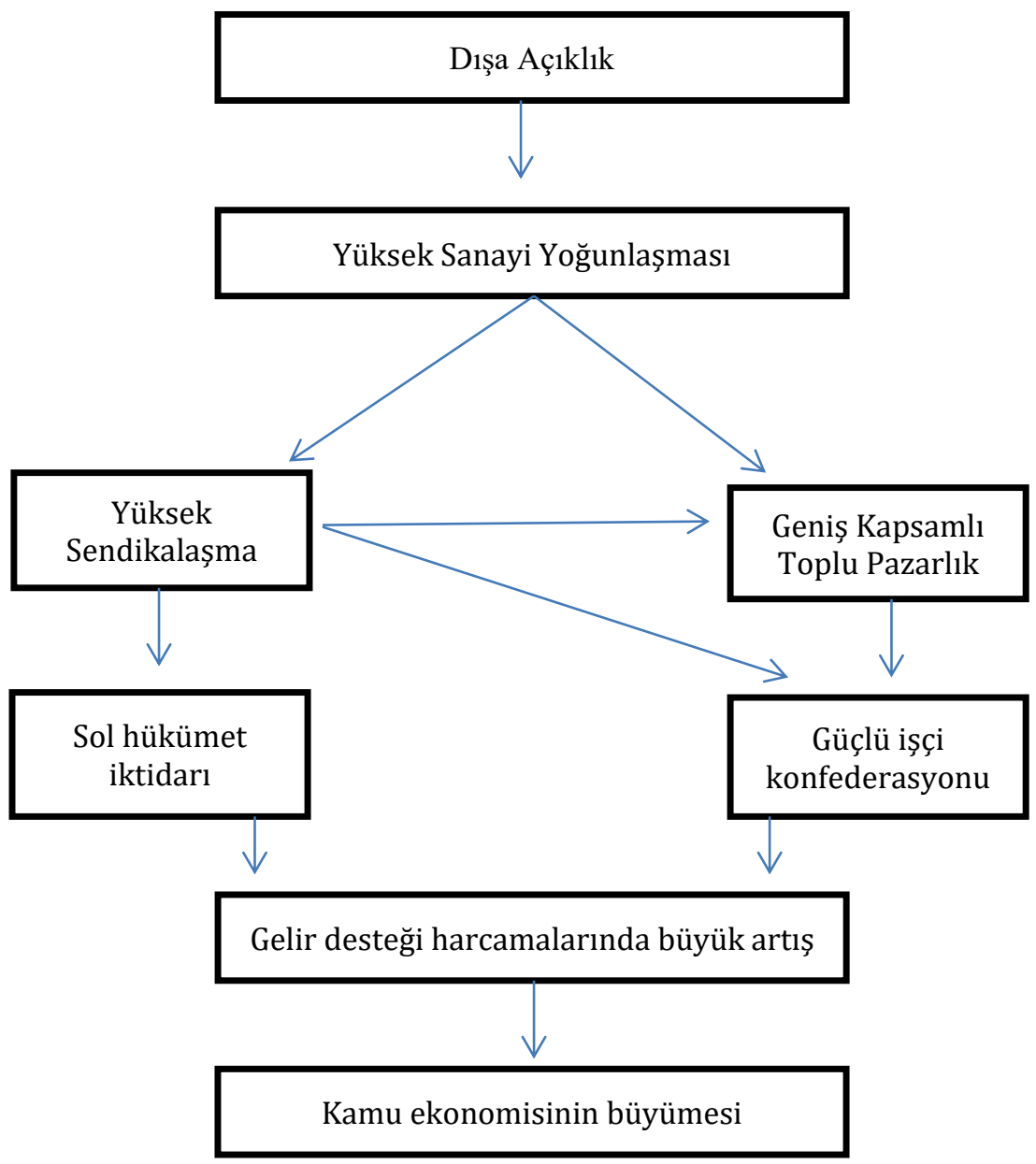

Şekil 1: Açık Ekonominin Kamu Ekonomisi Üzerindeki Etkisi

Kaynak: Cameron, 1978: 1256.

Telafi hipotezi bağlamında ele alındığında küreselleşmenin yarattığı riskler nedeniyle istihdamda yaşanan dalgalanmalar ve artan işsizlik karşısında, devlet sosyal güvenlik ve refah harcamaları yanında kamu sektörü istihdamını artırmak suretiyle ekonomiye müdahale etmektedir (Aytaç, 2018: 136).

Çalışmayla ilişkili olması noktasında orta gelirli ülkelerde küreselleşmenin kamu sektörü istihdamı üzerindeki etkisinin gösterilmesi amacıyla Şekil 2'de söz konusu değerler karşılaştırmalı olarak verilmiştir. Soldaki eksende kamu sektörü istihdamının toplam istihdam içerisindeki payı yer alırken, sağ eksende KOF küreselleşme endeksi yer almaktadır. 21. yüzyllı kapsayan zaman periyodu içerisinde her iki değişkenin eğilimi incelendiğinde, Ukrayna'nın incelenen ülkeler arasında en yüksek kamu istihdamına sahip ülke olarak öne çıktığı görülmektedir. Ukrayna'dan sonra Arjantin ve Kosta Rika sırasiyla en yüksek paya sahiptir. Romanya'da ise 2000'lerden itibaren 2007 yılına kadar belirgin bir düşüş yaşanmakla birlikte yeniden yükselme eğilimi ortaya çlkmış ve diğer ülkelerle aynı trende sahip olmuştur. Şekilde ortaya çlkan en önemli sonuç, küreselleşmenin dünya açısından keskin artışı karşısında, bu 
ülkelerde kamu sektörü istihdamının düşük seviyelerde ve istikrarlı bir eğilim göstermesidir.

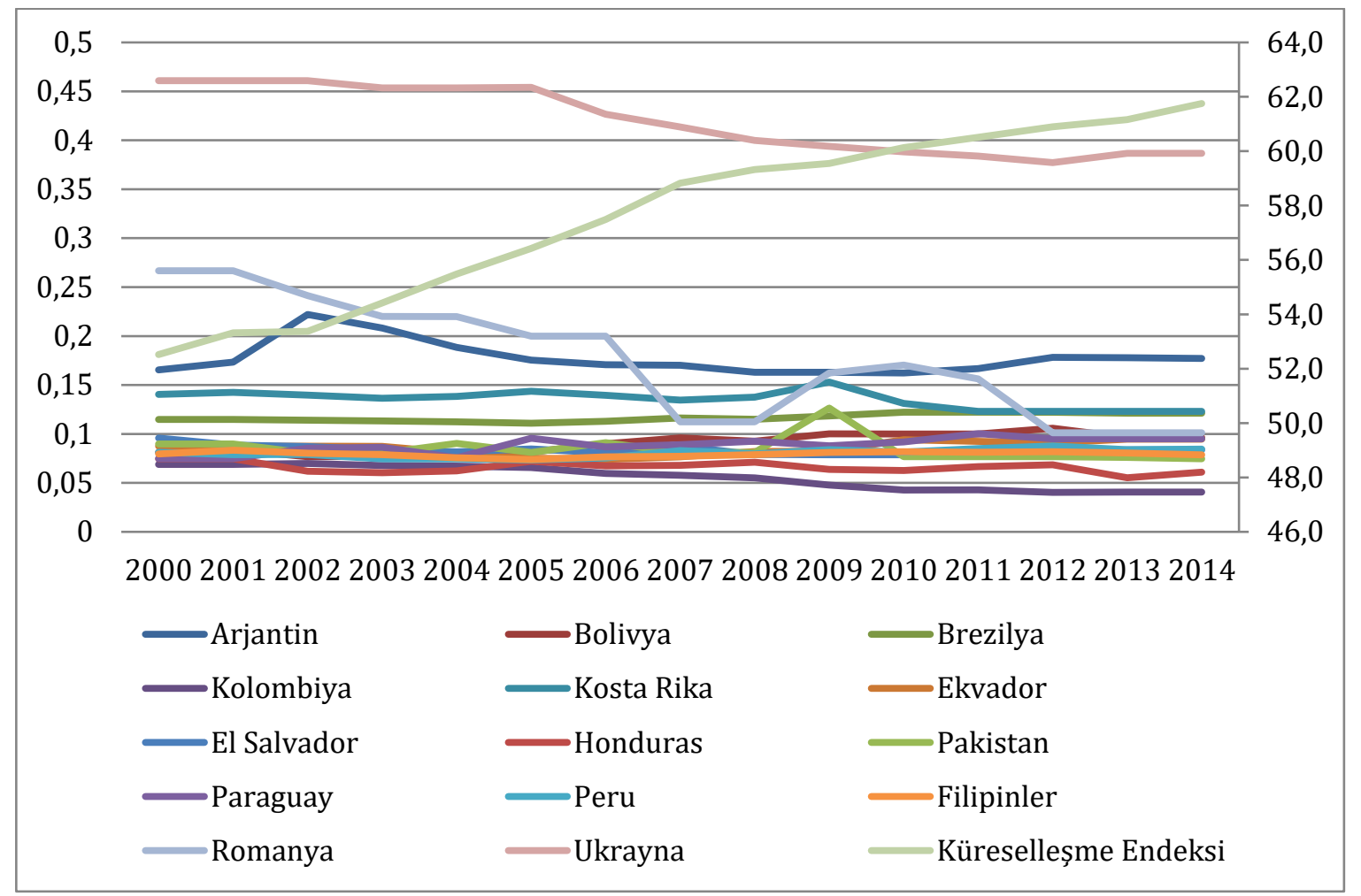

Şekil 2: Küreselleşme ve Kamu Sektörü İstihdamı

Kaynak: World Bank, 2018; Gygli vd., 2019

\section{LITERATÜR İNCELEMESI}

Küreselleşmenin kamu sektörü büyüklüğü ve kamu harcamaları üzerindeki etkisini inceleyen geniş bir literatürün olduğunu söylemek mümkündür. Özellikle Cameron (1978) ve Rodrik (1996)'in öncülük ettiği küreselleşmekamu harcamaları ilişkisi yaklaşımından hareketle farklı ülke grupları, zaman periyodu ve ekonometrik yöntemden kaynaklanan nedenlerle elde edilen sonuçlar değişmektedir. Kamu sektörü büyüklüğü olarak kamu harcamalarının payı ve bileșenleri yaygın olarak temel parametre olarak ele alınmakta; fakat doğrudan kamu istihdamını kullanan çalışmalar oldukça sınırlıdır. Küreselleşmenin kamu harcamalarının artmasına yol açan mekanizmalarından birisi Rodrik (1996)'e göre dışsal riskler sonucu artan işsizliğin azaltılması noktasında kamu istihdamının istikrar sağlayıcı güç olarak devreye girmesidir. $\mathrm{Bu}$ amaçla mevcut çalışma, küreselleşmenin kamu istihdamı kanalıyla kamu sektörünü nasıl etkilediğini ele alması bakımından farklılık arz etmektedir. Bu çerçevede ilgili literatüre katkı sağlaması beklenmektedir. Ampirik literatürde bahsedilen çalışmalar aşağıda özetlenmiştir.

"Rodrik (1996), geniş örneklem grubu için ticari açıklık ile kamu harcamalarının bileşenleri arasındaki etkileşimi analiz etmiştir. Elde edilen sonuçlar, kamu harcamalarının önemli derecede dişsal riske maruz kalan ülkelerde risk azaltıcı roller üstlendiğini göstermektedir. Diş ticaretteki belirsizlikler ve ihracattaki ürün yoğunlaşması gibi riskler ortaya çıktığında, dış ticaret açıklığı önemini kaybetmektedir. Dolayısıyla kamu harcamaları "koruyucu" faaliyet haline gelmektedir. Rodrik (2000), farklı dönemlere ait verilerle 130 gelişmekte olan ülkede dişsal riskin kamu sektörü istihdamına olan etkisini incelediği çalışmasında dışsal risklere büyük ölçüde maruz kalan ülkelerde kamu sektörü 
istihdamının ve kamu harcamalarının arttığını ortaya koymuştur. Nispeten daha fazla güvence sağlayan kamu istihdamı dışsal riske karşı bir nevi güvence sağlamaktadır.

Garrett (2001)'in, 100'den fazla ülke için 19701995 periyodu verileriyle yaptığı analizin sonuçlarına göre ticari küreselleşme yüksek kamu harcamalarına yol açarken, 1970-1984 ve 1985-1995 dönemleri arasında dış ticaretin daha hızlı büyüdüğü ülkelerde, iki dönem arasında hükümet harcamalarında daha düşük bir büyüme yaşanmıştır. Diğer yandan sermaye hareketliliğinin kamu harcamaları üzerinde herhangi bir etkisinin olmadı̆̆ sonucuna ulaşılmıştır.

Garrett ve Mitchell (2001), 18 OECD ülkesi için 1961-1993 dönemi verileriyle küreselleşmenin refah harcamaları üzerindeki etkisini analiz etmiştir. Toplam ticaret, ithalat, doğrudan yabancl yatırım ve finansal entegrasyon değişkenleri küreselleşmeyi temsil ederken, refah devleti uygulamaları olarak kamu harcamaları (sosyal hizmetler ve gelir transferine yönelik) ve vergilendirme kullanılmıştır. Elde edilen sonuçlara göre toplam ticaret ve finansal entegrasyon arttıkça kamu harcamaları azalmaktadır. Buna karşılık, uluslararası piyasalara entegrasyon ne sermaye vergilerinde azalmaya ne de vergi yükünün sermayeden tüketim ve emek gelirine kaymasına neden olmaktadır. Ayrıca, daha fazla doğrudan yabancı sermaye akımlarına sahip ülkeler sermayeyi daha fazla vergilendirme eğilimindedir.

Garen ve Trask (2005), yatay kesit yöntemiyle 1990 yılı verilerini kullanarak geleneksel bütçe harcamaları ve bütçe dışı kamusal harcamaları dikkate alarak, dışa açıklığın kamu sektörü büyüklügü üzerindeki etkisini ölçmüştür. Bütçe dışı unsurlar olarak devlet mülkiyetli şirketler, fiyat kontrolleri ve kamulaştırma dikkate alındığında, dışa daha az açık ekonomilerde kamu sektörünün payının daha yüksek olduğu bulgusuna ulașılmıștır. Ayrıca, bütçe dișı unsurların payının artması daha yüksek ticaret engelleriyle pozitif korelasyona sahiptir. Son olarak geleneksel bütçe unsurları göz önüne alındığında, daha büyük kamu sektörüne sahip ülkelerde ticaret şoklarından kaynaklanan risklere yönelik sosyal güvenlik harcamalarının arttığı görülmektedir.

Dreher vd. (2008b), küreselleşmenin kamu harcamalarının bileșenleri üzerindeki etkisini farklı veri seti ve çeşitli küreselleşme göstergeleri kullanarak incelemiștir. Ulașılan sonuçlara göre küreselleşme, kamu harcamalarının bileșenleri üzerinde önemli bir etkiye sahip değildir.

Busemeyer (2009), OECD ülkeleri için farklı zaman periyodu içeren yatay kesit ve panel yöntemiyle yaptığ küreselleșmenin kamu sektörünün payını azalttığını; fakat ulusal politikalardaki farklılıklar ve siyasi kurumların politik tavırlarının küreselleşme ile kamu sektörü arasındaki ilişkide belirleyici role sahip olduğunu ifade etmiştir.

Ram (2009), 154 ülke için 1960-2000 dönemini kapsayan 41 yıllık panel verisiyle dışa açıklık, ülke büyüklüğü ve kamu sektörü büyüklüğü arasındaki ilişkiyi incelemiştir. Havuzlanmış OLS tahmini sonuçları dışa açıklık, ülke büyüklüğü ve kamu sektörü büyüklügünün birbiriyle negatif ilişkili olduğunu göstermektedir. Ancak, ülkeler arasındaki heterojenlik, sabit etkiler modeli ile açıklandığında değişkenler arasındaki negatif ilişkiyi destekleyen çok az bulgu ortaya çlkmaktadır.

Epifani ve Gancia (2009), 143 ülke için ticaretin yurtiçindeki vergilendirme maliyetini düşürmesi yoluyla ticaret hadlerinin yarattığı dışsallık ile ticaretin riskleri ve kamu transferini artırarak, sosyal güvence talebi kanallarıyla dıșa açıklığın kamu büyüklügünü artırdığı hipotezini test etmiştir. Buna göre dişa açıklık ile kamu sektörü büyüklügü arasında pozitif ilişki söz konusu olmakla birlikte ticaret hadlerinin dışsallık etkisi, yerli ve yabancı mallar arasındaki düşük ikame esnekliğine bağlı olmaktadır.

Shahbaz vd. (2010), Pakistan ekonomisi için 1971-2006 periyodu verileriyle ticari ve 
finansal açıklığın kamu sektörü büyüklüğü üzerindeki etkisini ölçtükleri çalışmada, ticari açıklığın kamu sektörünü pozitif yönde etkilediğini, diğer ifadeyle ticari açıklık arttıkça kamu harcamalarının da arttığını ortaya koymuştur. Finansal açlklı ile kamu harcamaları arasında ise istatistiki olarak anlamlı bir ilişki tespit edilememiştir.

$\mathrm{Wu}$ ve Lin (2010), Panel veri yöntemiyle Çin'deki 30 eyalet için 1998-2006 dönemi verilerini kullanarak ticari açıklık ve doğrudan yabancı yatırımların (DYY) kamu sektörü üzerindeki etkisini analiz etmiştir. Elde edilen sonuçlara göre ticari açıklık ve DYY kamu sektörünün genişlemesini engellemektedir. Bu sonuçlar Wagner Yasasının Çin'de geçerli olmadığını ortaya koymakla birlikte, eyaletler düzeyinde kamu sektörünün ölçek ekonomileriyle karakterize olduğunu göstermektedir.

Abounoori ve Ghaderi (2011), 2000-2007 periyoduna ait verilerle MENA ülkelerinde ticari ve finansal açıklığın kamu sektörü büyüklüğü üzerindeki etkisini incelediği analizin sonuçları, kamu sektörü büyüklüğünün ticari açıklık ile pozitif; finansal açıklık ile negatif ilişsili olduğunu ortaya koymaktadır.

Benarroch ve Pandey (2012), 1972-2000 periyoduna ait verileri kullanarak düșük ve yüksek gelirli 119 ülkede dışa açıklık ile kamu harcamalarının bileșenleri arasındaki ilişkiyi araştırmıştır. Bütün ülkeler açısından ele alındığında, dışa açıklık ile toplam kamu harcamaları arasında herhangi bir nedensellik ilişkisi tespit edilememiştir. Sonuç, gelir grupları özelinde incelendiğinde de değişmemektedir. Dışa açıklık ile kamu harcamaları bileșenleri arasındaki ilișki incelendiğinde ise sadece düşük gelir grubunda dışa açıklık eğitim harcamalarını artırmaktadır. Yüksek gelirli ülke grubunda ise dışa açıklık, kamu sektörünün payını azaltmaktadır. Elde edilen sonuçlar telafi hipotezine karșıllk verimlilik hipotezini desteklemektedir.

Liberati (2013), 1962-2009 dönemi ve 156 ülke veri setinden oluşan çalışmasında telafi hipotezinin geçerliliğini test etmiștir. Elde edilen sonuçlar, telafi hipotezini desteklememektedir.

Ibrahim (2015), En büyük 5 Afrika ülkesi (Nijerya, Cezayir, Güney Afrika, Mısır ve Angola) için 1970-2010 döneminde ticari açıklık ile kamu sektörü büyüklügünü araștırmıștır. Bulgular, iki değişken arasında Nijerya ve Cezayir'de pozitif yönlü nedenselliği gösterirken, Güney Afrika'da negatif yönlü bir ilişkinin varlığına işaret etmektedir. Angola ve Mısır için her iki değişken arasında herhangi bir ilişski bulunmamıştır.

Aytaç (2018), Türkiye ekonomisi için 19802016 dönemine ait verilerle küreselleșme, işsizlik ve kamu sektörü istihdamı arasındaki ilişkiyi incelemiştir. Elde edilen sonuçlara göre küreselleşmeyle ortaya çıkan riskler sonucu artan işsizliğin azaltılması hususunda telafi hipotezini destekler biçimde kamu sektörü istihdamı artmaktadır.

Gözgör vd. (2019), 2000-2016 dönemi arasında 92 gelişmekte olan ülkede küreselleşmenin kamu sektörü istihdamı üzerindeki etkisini inceledikleri çalışmanın sonucunda verimlilik hipotezini destekleyen bulgulara ulaşmıştır. Diğer ifadeyle küreselleşme kamu sektörü istihdamını azaltmaktadır.

Cengiz ve Manga (2020), 2001-2017 döneminde $A B$ ülkelerinde küreselleşmenin kamu harcamalarının bileşenlerine etkisini inceledikleri çalışmada, küreselleşmenin kamu düzeni ve güvenlik, eğitim, sağlık ve sosyal koruma harcamaları üzerinde pozitif; genel kamu hizmetleri ve savunma harcamaları üzerinde ise negatif etkiye sahip olduğunu ortaya koymuştur.

Küreselleşme ile kamu politikaları arasındaki ilişkiyi ele çalışmalar ağırlıklı olarak kamu harcamaları ve kamu sektörünün büyüklügünnü ifade eden çeşitli göstergelere odaklanmaktadır. Küreselleşmenin kamu istihdamına etkisini ölçen çalışmaların sayısının çok sınırlı olduğu görülmektedir. Oysa gelişmekte olan ülkelerde küreselleşme sürecinde yaşanan kayıpların telafi 
edilebilmesinin yollarından birisi kamu istihdamıdır. $\mathrm{Bu}$ çerçevede mevcut çalışmada, küreselleşmeyle ilişkili olarak yaşanan istikrarsızlık ve kırılganlıklarla mücadelede kamusal politikaların önem kazandığı orta gelirli ülkelerde küreselleşme ve kamu istihdamı arasındaki ilişkinin araştırılması amaçlanmıştır.

\section{VERİ, MODEL VE YÖNTEM}

$\mathrm{Bu}$ çalışmanın temel amacı, Dünya bankası sinıflandırmasına göre orta gelirli ülkeler grubunda yer alan seçilmiş ülkelerdeki küreselleşme ile kamu sektörü arasındaki ilişkinin incelenmesidir. Veri setlerinin elde edilişi aşamasında oluşan kısıtlar nedeniyle ülkeler Arjantin, Bolivya, Brezilya, Kolombiya, Kosta Rika, Ekvador, El Salvador, Honduras, Pakistan, Paraguay, Peru, Filipinler, Romanya ve Ukrayna olarak seçilmiştir. 2000-2014 yılları arasındaki veri setleri kullanılarak yapılan analizin ampirik modeli Rodrik (1996), Aytaç (2018) ve Gözgör vd. (2019) çalışmasını takiben,

$\left(P E M P_{i t}\right)=f\left(G L O B_{i t}, G D P_{i t}, L A B O R_{i t}\right)$ şeklinde kurulmuştur.

Kurulan modelde yer alan ve bağımlı değişken olan $P E M P_{i t}$; toplam istihdam içerisinde kamu sektörü istihdamının payını (\%), GLOB $i t$; KOF küreselleşme endeksini (0-100), GDP $P_{i t}$; ekonomik büyüme göstergesi olarak 2010 sabit fiyatlarıyla dolar cinsinden kişi başına düşen reel GSYİH'yi, $L A B O R_{i t}$ ise 15 yaş üzeri toplam nüfus içerisindekilerin işgücüne katılım oranını (\%) göstermektedir.

Gygli vd. (2019) tarafından güncellenen KOF küreselleşme endeksinin seçilmesinin nedeni, bu yeni versiyonda daha kapsaml küreselleşme parametrelerine yer verilmesidir. De jure ve de facto şeklinde ayrıştırılarak ele alınan endekste, de facto fiili olarak gerçekleşen uluslararası akımları ve faaliyetleri ölçerken, $d e$ jure uluslararası akımları ve faaliyetleri kolaylaştıran, teşvik eden politikaları ve koşulları ölçmektedir. Genel KOF endeksi söz konusu de jure ve de facto ölçümlerin toplamından oluşmaktadır (Gygli vd., 2019:
544). Buna ilave olarak genel KOF küreselleşme endeksi, ekonomik, politik ve sosyal küreselleşme göstergelerinin bileşiminden oluşmaktadır. KOF ekonomik küreselleşme endeksi yerine genel KOF küreselleşme endeksinin kullanılmasının diğer nedeni ise sosyal ve politik küreselleşmenin de gelişmekte olan ülkelerde kamu politikaları üzerinde etkili olmasıdır.

Ampirik modelde yer alan $G D P_{i t}$ ve $L A B O R_{i t}$ kamu istihdamı üzerinde önemli bir etkiye sahip olduğunun düşünülmesi sebebiyle modele kontrol değişkenleri olarak eklenmiştir. Belirlenen modelin logaritmik formu;

$\ln P E M P_{i t}=\beta_{0}+\beta_{1} \ln G L O B_{i t}+\beta_{2} \ln G D P_{i t}+$ $\beta_{3} \ln L A B O R_{i t}+\varepsilon_{i t}$

ile gösterilmektedir. (1) nolu modelde yer alan LnPEMP; kamu istihdamının doğal logaritmasını, LnGLOB; küreselleşme göstergesinin doğal logaritmasını, LnGDP; kişi bașına düșen GSYİH'nin doğal logaritmasını, LnLABOR; işgücüne katılım oranının doğal logaritmasını, $\varepsilon_{t}$ ise hata terimini ifade etmektedir. Kullanılan değişkenlerden kamu sektörü istihdamı, ekonomik büyüme ve işgücüne katılım oranı, World Bank (2018) [Worldwide Bureaucracy Indicators-WWBI] veri tabanından; küreselleşme göstergesi ise Dreher (2006) ve Dreher vd. (2008a) tarafından ortaya atılan ve Gygli vd. (2019) çalışması tarafından geliştirilen KOF endeksi verilerinden elde edilmiştir.

Çalışmanın analiz kısmında ilk olarak belirlenen seriler için tanımlayıcı istatistikler incelenmiştir. Sonrasında panel grubunu oluşturan ülke grubu arasında yatay kesit bağımlılığı olup olmadığı araştırılmıştır. Bu amaçla, öncelikle Breusch ve Pagan (1980) tarafından geliştirilen Lagrange Çarpanı (LM) testinden faydalanılmıştır. $\mathrm{T}>\mathrm{N}$ olması durumunda anlamlı sonuçlar veren LM testi;

$y_{i t}=a_{i}+\beta_{i} x_{i t}+\varepsilon_{i t} i=1 \ldots, N, t=1 \ldots, T$

şeklinde ifade edilmektedir. $\mathrm{N}>\mathrm{T}$ olması durumunda ise Pesaran (2004) tarafindan türetilen ADF regresyonunun tahmininden elde edilen kalıntıların kullanıldığı CD testi 
kullanılmaktadır. CD testi hesaplamasında, her birimin kendisi dışında kalan tüm birimlerle otokorelasyonu hesaplanmakta ve $\mathrm{N}$ birim boyuttaki otokorelasyon sayısı, $\mathrm{N}^{*}(\mathrm{~N}-1)$ adete kadar hesaplanmaktadır (Tatoğlu, 2017: 105).

Dengeli panel için CD testi;

$C D=\sqrt{\left(\frac{2 T}{N(N-1)}\right)} \sum_{i=1}^{N-1} \sum_{j=i+1}^{N}\left(\hat{\rho}_{i j}-1\right) \sim N(0,1)$

şeklinde hesaplanmaktadır. Buna karşın bazı durumlarda $\mathrm{CD}$ testinin gücünün azalması nedeniyle Pesaran vd. (2008), LM testinin düzenlenmiş versiyonu olan testi geliştirmişlerdir;

$L M_{a d j}=$

$\sqrt{\left(\frac{2}{N(N-1)}\right)} \sum_{i=1}^{N-1} \sum_{j=i+1}^{N} \hat{\rho}_{i j} \frac{(T-k) \widehat{\rho}_{i j}^{2}-\mu_{T i j}}{\sqrt{v_{T i j}^{2}}} \sim N(0,1)$

denklemdeki ifadelerden $\mathrm{k}, \mu_{\mathrm{Tij}}$ ve $v_{\mathrm{Tij}}^{2}$ sırasıyla açıklayıcı değişken sayısını, ortalamayı ve ( $\mathrm{T}$ k) $\hat{\rho}_{\mathrm{ij}}^{2}$ 'nin varyansını temsil etmektedir (Pesaran vd., 2008).

Yapılan analizde yatay kesit bağımlılığının test edilmesi sonrasında yatay kesitlerin kendi içinde bağımsız dinamikleri olup olmadığını gösteren eğimin homojenitesi testinin de uygulanması gerekmektedir. Bu amaçla ilk olarak Swamy (1970) testinden faydalanılmıștır. Bu test için, kesitler arasında homojen bir ilişki olduğunu gösteren hipotez;

$H_{0}: \beta_{1}=\beta_{2}=\cdots=\beta_{N}=\beta$

şeklinde

kurulmaktadır (Swamy, 1970: 320).

Swamy (1970) testine ek olarak, homojenite testi olarak Pesaran ve Yamagata (2008) tarafından geliştirilen $\tilde{\Delta}$ testi de kullanılmaktadır.

Testin temel hipotezleri;

$H_{0}: \beta_{i}=\beta$ "eğim katsayıları homojendir"

$H_{1}: \beta_{i} \neq \beta$ "eğim katsayıları homojen değildir" şeklinde olan Pesaran ve Yamagata (2008) testi bir başka homojenite testi olan Swamy (1970) testinin geliștirilmiș halidir.
Elde edilen yatay kesit bulgularına paralel uygulanan birim kök testi olarak, yatay kesit bağımlılığını göz önünde tutan, ikinci nesil testlerden Pesaran (2007) tarafından geliștirilen Yatay kesit Genişletilmiş Im, Pesaran ve Shin (Cross-Sectionally Augmented IPS-CIPS) testi kullanılmıștır. Bu test, her bir yatay kesite ait birim kök test istatistiklerinin ortalaması alınarak panelin geneli için hesaplanan birim kök testlerinden elde edilmektedir. CIPS;

CIPS $=\frac{1}{N} \sum_{i=1}^{N} t_{i}(N, T)$

şeklinde hesaplanabilir. CIPS birim kök testi için gerekli olan kritik değerler ise Pesaran (2007) çalışmasına göre belirlenmektedir. Değişkenlerin farklı düzeyde durağan olmasına bağlı olarak yapılan analizin devamında eşbütünleşme testi uygulanmamıștır.

Değişkenler arasındaki uzun dönemli ilişkinin tahmininde, farklı düzeylerden bütünleşik seriler arasındaki uzun dönemli ilişkinin incelenmesine olanak sağlayan ve Eberhardt ve Bond (2009) tarafından geliştirilen AMG (Augmented Mean Group) yöntemi kullanılmaktadır. Bu testin kullanılmasındaki en önemli gerekçe, durağan olan ve olmayan seriler ile analize aynı denklem içerisinde izin vermesidir (Eberhardt ve Bond, 2009).

AMG yöntemi,

$i=1,2, \ldots, N$, $t=1,2, \ldots, T, \quad$ ve $\quad m=1,2, \ldots, k$

varsayımları altında,

$$
\begin{aligned}
& y_{i t}=\beta_{i}^{\prime} x_{i t}+u_{i t} u_{i t}=\alpha_{i}+\lambda_{i}^{\prime} f_{t}+\varepsilon_{i t} \\
& x_{m i t}=\pi_{m i}+\delta_{m i}^{\prime} g_{m t}+\rho_{1 m i} f_{1 m t}+\ldots+\rho_{n m i} f_{n m t}+v_{m i t}
\end{aligned}
$$

(7) nolu denklemde yer alan

$f_{. m t} \subset f_{t} f_{t}=\varsigma^{\prime} f_{t-1}+\varepsilon_{t} g_{t}=\tau^{\prime} g_{t-1}+\varepsilon_{t}$

(6) nolu eşitlikte yer alan $x_{i t}$, gözlenebilen vektör kovaryanslarını göstermektedir. Gözlenemeyen değişkenler $u_{i t}$, kombinasyon 
grup spesifikasyon etkileri $\alpha_{i}$ ile, ortak faktörler $f_{t}$ ve grup spesifik faktör ağırlıkları $\lambda_{i}$ ile gösterilmektedir. (8) nolu eşitlikte yer alan $f_{t}$ gözlenemeyen ortak faktörleri, $g_{t}$ ise nispi grup spesifikasyon faktör ağırlıklarını temsil etmektedir. AMG modelinin uygulanmasında;

AMG I. Adım: $\Delta y_{i t}=b^{\prime} \Delta x_{i t}+\sum_{t=2}^{T} c_{t} \Delta D_{t}+e_{i t}$ $\Rightarrow \hat{c}_{t} \equiv \hat{m}_{t}^{\bullet}$

AMG II. Adım: $y_{i t}=\alpha_{i}+b_{i}^{\prime} x_{i t}+c_{i} t+d_{i} \hat{m}_{t}^{-}+e_{i t}$ $\Rightarrow \hat{b}_{A M G}=N^{-1} \sum_{i} \hat{b}_{i}$

izlenmektedir. İlk aşamadaki denklem En Küçük Kareler Regresyonunu temsil etmektedir. Eşitlikte yer alan $\Delta D_{t}$, farkı alınmış serileri, $T-1$ periyot kuklalarını, $\hat{m}_{t}^{\bullet}$ ise tahmin katsayılarını temsil etmektedir. İkinci aşamayı gösteren denklemde yer alan $\hat{m}_{t}^{\bullet}$ ise $\mathrm{N}$ grup spesifik regresyonunu, $\widehat{b_{l}}$ ise, Pesaran ve Smith (1995) tarafindan ortaya atılan ortalama grup yaklaşımını takiben bireysel katsayı tahminlerinin ortalamasını temsil etmektedir.

Değişkenler arasındaki nedensellik ilişkisinin tespit edilmesinde ise Kónya (2006) tarafından geliştirilen panel bootstrap nedensellik yöntemi kullanılmıştır. Değişkenler arasındaki nedensellik ilişkisinin ülke özelinde ortaya konulmasına olanak sağlayan bu yöntem, SUR sistemlerine ve Wald testine dayalı olarak bootstrap kritik değerlerine dayalı olan değişkenlerin birim kök ve eşbütünleşme gibi ön test yapmaya gerek duyulmadan, ülkeler arasındaki eşzamanlı korelasyona izin vererek, panel veri tarafından sağlanan ek bilgilerin kullanılmasına imkân sağlamaktadır. Ayrıca kullanılan bu yöntemde diğer önemli olan nokta, gecikme uzunluğunun doğru olarak seçilmesidir (Kónya, 2006: 990-991).

Kónya (2006) yöntemine göre değişkenler arasındaki nedensellik ilişkisinin tespit edilmesi amacıyla kurulan modeller iki farklı denklem sistemi ile ifade edilmektedir. Bunlar;

$$
\begin{aligned}
Y_{1, t}=\alpha_{1,1}+\sum_{i=1}^{l y_{1}} \beta_{1,1, i} Y_{1, t-i} \\
+\sum_{i=1}^{l x_{1}} \gamma_{1,1, i} X_{k, 1, t-i}+\epsilon_{1,1, t} \\
\cdot \\
\cdot \\
\cdot \\
Y_{2, t}=\alpha_{1,2}+\sum_{i=1}^{l y_{1}} \beta_{1,2, i} Y_{2, t-i} \\
+\sum_{i=1}^{l x_{1}} \gamma_{1,2, i} X_{k, 2, t-i}+\epsilon_{1,2, t} \\
\cdot \\
\cdot \\
+\sum_{i=1}^{l y_{1}} \gamma_{1, N, i} X_{k, N, t-i}+\epsilon_{1, N, t} \\
Y_{N, t} \beta_{1, N, i} Y_{N, t-i}
\end{aligned}
$$

ve

$$
\begin{aligned}
X_{k, 1, t}=\alpha_{2,1} & +\sum_{i=1}^{l y_{2}} \beta_{2,1, i} Y_{1, t-i} \\
& +\sum_{i=1}^{l x_{2}} \gamma_{2,1, i} X_{k, 1, t-i}+\epsilon_{2,1, t}
\end{aligned}
$$




$$
\begin{gathered}
X_{k, 2, t}=\alpha_{2,2}+\sum_{i=1}^{l y_{2}} \beta_{2,2, i} Y_{2, t-i} \\
+\sum_{i=1}^{l x_{2}} \gamma_{2,2, i} X_{k, 2, t-i}+\epsilon_{2,2, t} \\
\cdot \\
\cdot \quad X_{k, N, t=\alpha_{2, N}}+\sum_{i=1}^{l y_{2}} \beta_{2, N, i} Y_{2, t-i} \\
+\sum_{i=1}^{l x_{2}} \gamma_{2, N, i} X_{k, N, t-i}+\epsilon_{2, N, t}
\end{gathered}
$$

şeklinde ifade edilebilir. Modellerde yer alan Y değişkeni, kamu sektörü istihdamını ifade ederken, $\mathrm{X}_{\mathrm{k}}$ kamu istihdamının önemli belirleyicilerinden olan küreselleşme endeksi, ekonomik büyüme ve işgücüne katılım oranını ifade etmektedir. Ayrica modellerde yer alan $N$, ülke sayısını $t$ zaman periyodunu, $l$ ise optimal gecikme uzunluğunu açıklamaktadır. Optimal gecikme uzunluğunun seçiminde Kónya (2006)'nın çalışmasında 1-4 arasında gecikme uzunluğu kullanılabileceği vurgulanmaktadır. $\mathrm{Bu}$ çerçevede mevcut çalışmada, Schwarz Bayesian Kriterine göre optimal gecikme uzunluğu seçilmiştir (Kónya, 2006: 982).

\section{BULGULAR}

Ampirik analiz aşamasında ilk olarak kurulan modelde yer alan parametreler için tanımlayıcı istatistikler ele alınmıştır. Tanımlayıcı istatistiklere yönelik bulgular Tablo 1'de yer almaktadır.

Tablo 1: Tanımlayıcı İstatistikler

\begin{tabular}{|l|c|c|c|c|}
\hline & LnPEMP & LnGLOB & LnGDP & LnLABOR \\
\hline Ortalama & 0.124 & 1.792 & 10.956 & 1.800 \\
\hline Medyan & 0.087 & 1.792 & 11.082 & 1.799 \\
\hline Maksimum & 0.460 & 1.898 & 12.384 & 1.897 \\
\hline Minimum & 0.040 & 1.666 & 10.024 & 1.705 \\
\hline St. Sapma & 0.091 & 0.044 & 0.591 & 0.045 \\
\hline Carpıklık & 2.472 & -0.201 & 0.415 & -0.223 \\
\hline Basıklık & 8.471 & 3.163 & 2.687 & 2.591 \\
\hline $\begin{array}{l}\text { Gözlem } \\
\text { Sayısı }\end{array}$ & 210 & 210 & 210 & 210 \\
\hline
\end{tabular}

Elde edilen bulgulara göre, seçilmiș ülkelerde 2000-2014 yılları arasında kurulan modelde bağımlı değişken olan LnPEMP, ortalama 0.124, maksimum 0.460 ve minimum 0.040 düzeylerinde değerler almıștır. Bağımlı değişkenlerden LnGLOB 1.792, LnGDP 10.956 ve LnLABOR ise 1.800 düzeyinde değerler almıştır. Çarpıklık değerlerine göre LnPEMP ve LnGDP değişkenleri sağa, LnGLOB ve LnLABOR ise sola çarpıktır. Basıklık değerine göre ise LnPEMP ve LnGLOB değişkenlerinin dik, LnGDP ve LnLABOR değişkenlerinin ise basık olduğu söylenebilir. Tablo 2'de panel grubunu oluşturan yatay kesitler arasındaki bağımlılığı ve eğim homojenitesini gösteren bulgulara yer verilmektedir.

Tablo 2: Yatay Kesit ve Homojenite Testi

Bulguları

\begin{tabular}{|c|c|c|c|c|}
\hline Test & LnPEMP & LnGLOB & LnGDP & LnLABOR \\
\hline $\mathrm{LM}$ & $180.029^{* * *}$ & $158.082^{* *}$ & $217.726^{* * *}$ & $236.305^{* * *}$ \\
\hline $\mathrm{CD}_{\mathrm{LM}}$ & $3.875^{* * *}$ & $2.458^{* * *}$ & $6.308^{* * *}$ & $7.507^{* * *}$ \\
\hline $\mathrm{CD}$ & $-2.081^{* * *}$ & $-2.202^{* *}$ & $-2.253^{* *}$ & $-2.089^{* *}$ \\
\hline Lamada & $2.659^{* * *}$ & $3.078^{* * *}$ & $6.069^{* * *}$ & $3.961^{* * *}$ \\
\hline \multicolumn{5}{|c|}{ Homojenlik Test İstatistiği } \\
\hline Swamy & $3639.32^{* * *}$ & $656.43^{* * *}$ & $15236.47^{* * *}$ & $10080.95^{* * *}$ \\
\hline$\ddot{\Delta}$ & $6.274^{* * *}$ & $10.842^{* * *}$ & $11.709^{* * *}$ & $5.632^{* * *}$ \\
\hline$\ddot{\Delta}_{\text {adj }}$ & $7.567^{* * *}$ & $13.076^{* * *}$ & $14.122^{* * *}$ & $6.792^{* * *}$ \\
\hline
\end{tabular}

Not: ${ }^{* * *, * * ;} \% 10, \% 5$ ve $\% 1$ düzeyinde anlamlılı̆̆ ifade etmektedir.

Elde edilen yatay kesit testi bulgularına göre uygulanan testlerin temel hipotezlerinin (yatay kesitler arasında bağımlılık yoktur) reddedilerek, seriler arasinda yatay kesit bağımlılığı olduğu görülmektedir. Ayrıca homojenite testi bulgularına göre de temel hipotezin reddedilmesine bağlı olarak ülkelerin kendilerine özgü dinamik yapılarının olduğu tahmin edilmiştir. Değişkenlerin birim kök sınaması amacıyla kullanılan CIPS birim kök testi bulguları ise Tablo 3'te yer almaktadır.

Tablo 3: CIPS Birim Kök Testi Bulguları

\begin{tabular}{|l|c|c|c|}
\hline & \multicolumn{3}{|c|}{ CIPS Birim Kök Testi } \\
\hline Değişkenler & $\begin{array}{c}\text { Düzey } \\
\text { Seviyede }\end{array}$ & 1.Fark & Bulgu \\
\hline LnPEMP & -2.060 & $-3.522^{* * *}$ & $\mathrm{I}(1)$ \\
\hline LnGLOB & $-3.272^{* * *}$ & - & $\mathrm{I}(0)$ \\
\hline LnGDP & -1.503 & $-2.696^{* * *}$ & $\mathrm{I}(1)$ \\
\hline LnLABOR & -1.901 & $-3.208^{* * *}$ & $\mathrm{I}(1)$ \\
\hline \multicolumn{4}{|l|}{ Kritik değerler: \%10 (-2.16) - \%5 (-2.28) - \%1 (-2.52) } \\
\hline
\end{tabular}

Not: $*, * *, * * ; \% 10, \% 5$ ve $\% 1$ düzeyinde anlamlılığ ifade etmektedir. 
Elde edilen birim kök testi bulgularına göre, LnPEMP, LNGDP ve LnLABOR değişkenleri düzeyde birim kök içerdiğinden farkı alınarak durağan hâle gelmiştir. Bu doğrultuda bu değişkenler için I(1) olduğu söylenebilir. Küreselleşme göstergesi olan LnGLOB ise diğer değişkenlerden farklı olarak düzeyde durağanlık göstermiştir. Diğer bir ifadeyle bu değişkenin I(0) olduğu söylenebilir. Farklı düzeyde durağanlık gösteren değişkenlerden oluşan bir model için uzun dönemli katsayı ilişkisinin tahmin edilmesine imkân sağlayan AMG katsayı tahmincisi bulguları ise Tablo 4'te yer almaktadır.

Tablo 4: AMG Testi Bulguları

\begin{tabular}{|c|c|c|c|c|}
\hline Ülkeler & LnGLOB & LnGDP & LnLABOR & $\begin{array}{c}\text { Sabit } \\
\text { Terim }\end{array}$ \\
\hline Arjantin & -1.158 & $-0.0002^{*}$ & -3.460 & $7.817^{* *}$ \\
\hline Bolivya & 0.327 & $-0.001^{* * *}$ & $-1.928^{* * *}$ & $2.111^{*}$ \\
\hline Brezilya & 0.487 & -0.005 & $-1.642^{* * *}$ & $1.233^{* *}$ \\
\hline Kolombiya & -0.549 & -0.001 & $-2.424^{* * *}$ & $4.306^{* * *}$ \\
\hline Kosta Rika & 0.835 & $-0.009^{* * *}$ & $1.083^{* * *}$ & $-3.716^{* *}$ \\
\hline Ekvador & -0.398 & 2.520 & $-3.298^{* * *}$ & $5.648^{* * *}$ \\
\hline El Salvador & $-1.017^{* *}$ & 0.001 & 1.095 & -1.498 \\
\hline Honduras & -1.587 & -0.006 & $-2.485^{* *}$ & 6.115 \\
\hline Pakistan & -5.380 & -0.001 & -4.850 & $16.875^{*}$ \\
\hline Paraguay & -1.374 & -2.890 & -0.610 & 2.518 \\
\hline Peru & $-1.787^{* * *}$ & $0.002^{* *}$ & $1.173^{* *}$ & -0.261 \\
\hline Filipinler & $-1.059^{* *}$ & 0.0001 & -0.717 & 2.092 \\
\hline Romanya & -2.184 & $-0.001^{* * *}$ & $-2.454^{* *}$ & 8.579 \\
\hline Ukrayna & $-1.611^{* * *}$ & 0.001 & 0.237 & $2.123^{*}$ \\
\hline PANEL & - & $-\mathbf{0 . 0 0 3}$ & $\mathbf{- 1 . 4 4 8 ^ { * * * }}$ & $\mathbf{3 . 8 5 3 ^ { * * * }}$ \\
\hline & $\mathbf{1 . 1 7 5 ^ { * * * }}$ & & & \\
\hline
\end{tabular}

Not: $*, * *, * * * ; \% 10, \% 5$ ve $\% 1$ düzeyinde anlamlılığı ifade etmektedir.

Değişkenler arasındaki uzun dönemli ilişsiyi gösteren bulgulara göre tüm panel grubu için kamu istihdamı; küreselleșme, ekonomik büyüme ve işgücüne katılım oranından istatistiki olarak anlamlı olmak üzere negatif yönde etkilenmektedir. AMG bulguları, ülke özelinde incelendiğinde küreselleşmenin kamu istihdamı üzerindeki etkisinin El Salvador, Peru, Filipinler ve Ukrayna'da negatif olduğu görülmektedir. Ekonomik büyüme kamu istihdamını Arjantin, Bolivya, Kosta Rika ve Romanya'da negatif; Peru'da ise pozitif yönde etkilemektedir. İşgücüne katılım oranının kamu istihdamı üzerindeki etkisi incelendiğinde Bolivya, Brezilya, Kolombiya, Ekvador, Honduras ve Romanya'da negatif; Kosta Rika ve Peru'da ise pozitif olduğu görülmektedir.

Kamu istihdamı ile küreselleşme arasındaki nedensellik ilişkisinin tahmin edilmesi amaciyla uygulanan Kónya (2006) nedensellik testi bulguları Tablo 5 'te verilmektedir.

Tablo 5’e göre Bolivya, Brezilya, Honduras, Pakistan ve Peru'da küreselleşmeden kamu istihdamına doğru tek yönlü nedensellik ilişkisi söz konusudur. Kamu istihdamından küreselleşmeye doğru nedensellik ilişkisine yönelik bulgular incelendiğinde ise kamu istihdamının küreselleşmenin nedeni olmadığ yönündeki temel hipotezin tüm ülkeler için kabul edildiği görülmektedir. Kamu istihdamı ile ekonomik büyüme arasındaki nedensellik ilişkisini gösteren bulgular Tablo 6'da yer almaktadır.

Tablo 5: Kamu İstihdamı ile Küreselleşme Arasındaki İlişki

\begin{tabular}{|c|c|c|c|c|c|c|c|c|}
\hline \multirow[t]{3}{*}{ Ülkeler } & \multicolumn{4}{|c|}{$\mathrm{H}_{0}:$ LnGLOB $\rightarrow$ LnPEMP } & \multicolumn{4}{|c|}{$\mathrm{H}_{0}:$ LnPEMP $\rightarrow$ LnGLOB } \\
\hline & \multirow[b]{2}{*}{ İstatistik } & \multicolumn{3}{|c|}{ Kritik Değerler } & \multirow[b]{2}{*}{ İstatistik } & \multicolumn{3}{|c|}{ Kritik Değerler } \\
\hline & & \%1 & $\% 5$ & \%10 & & $\% 1$ & $\% 5$ & \%10 \\
\hline Arjantin & 17.199 & 3254.00 & 483.020 & 381.125 & 58.6360 & 1574.6 & 819.361 & 409.989 \\
\hline Bolivya & $2860.65^{* * *}$ & 1601.91 & 400.923 & 280.062 & 58.1070 & 6161.4 & 1989.97 & 304.640 \\
\hline Brezilya & $2264.23^{* *}$ & 3068.62 & 738.603 & 303.304 & 42.2860 & 1241.5 & 699.421 & 263.761 \\
\hline Kolombiya & 0.007 & 1742.22 & 565.085 & 249.430 & 46.688 & 4235.3 & 693.176 & 283.120 \\
\hline Kosta Rika & 0.811 & 2053.42 & 391.795 & 202.985 & 47.327 & 3248.5 & 1349.94 & 583.794 \\
\hline Ekvador & -12.031 & 1388.16 & 530.695 & 260.016 & 69.821 & 1721.8 & 622.515 & 305.802 \\
\hline El Salvador & 18.847 & 2702.04 & 891.262 & 258.443 & 58.345 & 2273.4 & 500.251 & 277.267 \\
\hline Honduras & $239.505^{*}$ & 896.59 & 512.917 & 197.323 & 45.093 & 1154.4 & 745.349 & 341.898 \\
\hline Pakistan & $502.467^{*}$ & 7112.46 & 2590.973 & 339.767 & 19.797 & 7252.0 & 1202.20 & 353.941 \\
\hline Paraguay & 144.733 & 7375.39 & 1163.453 & 334.484 & 4.476 & 2426.0 & 657.140 & 285.473 \\
\hline Peru & $3609.722^{* *}$ & 4553.49 & 554.680 & 377.877 & 16.854 & 4423.4 & 532.945 & 253.558 \\
\hline Filipinler & 161.022 & 11174.41 & 495.424 & 276.695 & 4.920 & 6251.0 & 1938.75 & 940.501 \\
\hline Romanya & 190.261 & 4075.42 & 1479.453 & 302.933 & 63.125 & 1103.5 & 385.997 & 224.733 \\
\hline Ukrayna & -617.621 & 2436.98 & 386.748 & 222.990 & 28.632 & 7239.6 & 1300.89 & 298.816 \\
\hline
\end{tabular}


Tablo 6: Kamu İstihdamı ile Ekonomik Büyüme Arasındaki İlișki

\begin{tabular}{|c|c|c|c|c|c|c|c|c|}
\hline \multirow[t]{3}{*}{ Ülkeler } & \multicolumn{4}{|c|}{$\mathrm{H}_{\mathrm{o}}:$ LnGDP $\rightarrow$ LnPEMP } & \multicolumn{4}{|c|}{$\mathrm{H}_{\mathrm{o}}:$ LnPEMP $\rightarrow$ LnGDP } \\
\hline & \multirow[b]{2}{*}{ İstatistik } & \multicolumn{3}{|c|}{ Kritik Değerler } & \multirow[b]{2}{*}{ İstatistik } & \multicolumn{3}{|c|}{ Kritik Değerler } \\
\hline & & $\% 1$ & $\% 5$ & \%10 & & $\% 1$ & $\% 5$ & \%10 \\
\hline Arjantin & 194.464 & 1308.254 & 711.705 & 359.55 & $433.710^{*}$ & 3084.69 & 654.33 & 312.72 \\
\hline Bolivya & $699.619^{* *}$ & 3394.203 & 535.580 & 300.672 & 122.629 & 7929.15 & 1110.3 & 285.47 \\
\hline Brezilya & $1408.46^{* * *}$ & 828.717 & 284.037 & 226.732 & 34.178 & 1632.99 & 462.43 & 150.31 \\
\hline Kolombiya & 152.022 & 898.828 & 423.206 & 192.714 & -546.925 & 2731.68 & 1183.5 & 345.76 \\
\hline Kosta Rika & 0.736 & 1159.785 & 305.690 & 236.322 & $902.121^{* *}$ & 1712.17 & 761.67 & 243.99 \\
\hline Ekvador & $70766.1^{* * *}$ & 4818.819 & 977.774 & 356.195 & $322.638^{*}$ & 4922.72 & 997.83 & 264.71 \\
\hline El Salvador & $1135.19^{* *}$ & 10653.90 & 548.697 & 281.979 & $704.085^{* *}$ & 2160.03 & 1021.4 & 354.55 \\
\hline Honduras & $805.76^{* *}$ & 973.067 & 484.044 & 319.233 & $277.060^{* *}$ & 3749.83 & 365.57 & 209.50 \\
\hline Pakistan & -630.984 & 1489.445 & 665.105 & 350.720 & 217.400 & 2090.04 & 1309.5 & 373.87 \\
\hline Paraguay & $1577.96^{* *}$ & 2353.409 & 1183.66 & 403.320 & $511.476^{*}$ & 3827.40 & 1287.2 & 506.29 \\
\hline Peru & 213.62 & 2358.787 & 693.129 & 224.169 & 0.111 & 2328.61 & 450.86 & 258.25 \\
\hline Filipinler & 45.3 & 508.369 & 355.894 & 264.379 & -285.870 & 43684.8 & 516.66 & 182.80 \\
\hline Romanya & $446.22^{* *}$ & 2410.562 & 358.833 & 219.207 & 50.174 & 5985.6 & 1673.0 & 567.41 \\
\hline Ukrayna & 18.891 & 2507.047 & 605.952 & 249.222 & 10.743 & 1048.9 & 303.63 & 140.80 \\
\hline
\end{tabular}

Not: ${ }^{*}, * * * * ; \% 10, \% 5$ ve \%1 düzeyinde anlamlılı̆̆ ifade etmektedir. Kritik değerler 1000 boostrap döngüsü ile elde edilmiștir.

Kamu istihdamı ile ekonomik büyüme arasındaki nedensellik ilişkisinin tespit edilmesi amacıyla yapılan test sonuçlarına göre Ekvador, El Salvador, Honduras ve Paraguay'da her iki değişken arasında çift yönlü nedensellik ilişkisi söz konusudur. Buna ilave olarak Bolivya, Brezilya ve Romanya'da ekonomik büyümeden kamu istihdamına; Arjantin ve Kosta Rika'da ise kamu istihdamından ekonomik büyümeye doğru tek yönlü nedensellik ilişkisi tespit edilmiştir. Kamu istihdamı ile işgücüne katılım oranı arasındaki nedensellik ilişkisi bulguları ise Tablo 7'de yer almaktadır.

Tablo 7: Kamu İstihdamı ile İşgücüne Katılım Oranı Arasındaki İlişsi

\begin{tabular}{|c|c|c|c|c|c|c|c|c|}
\hline \multirow[t]{3}{*}{ Ülkeler } & \multicolumn{4}{|c|}{$\mathrm{H}_{\mathrm{o}}:$ LnLABOR $\rightarrow$ LnPEMP } & \multicolumn{4}{|c|}{$\mathrm{H}_{0}:$ LnPEMP $\rightarrow$ LnLABOR } \\
\hline & \multirow[b]{2}{*}{ İstatistik } & \multicolumn{3}{|c|}{ Kritik Değerler } & \multirow[b]{2}{*}{ İstatistik } & \multicolumn{3}{|c|}{ Kritik Değerler } \\
\hline & & $\% 1$ & $\% 5$ & $\% 10$ & & $\% 1$ & $\% 5$ & $\% 10$ \\
\hline Arjantin & $192.700^{* *}$ & 449.821 & 61.450 & 42.280 & $2085.68^{* *}$ & 3470.43 & 776.17 & 429.63 \\
\hline Bolivya & -302.759 & 698.706 & 216.781 & 85.606 & $936.838^{* *}$ & 4208.59 & 616.51 & 332.33 \\
\hline Brezilya & 26.252 & 580.054 & 295.992 & 57.543 & 37.934 & 1282.27 & 454.57 & 162.66 \\
\hline Kolombiya & 153.852* & 574.236 & 224.827 & 64.387 & 588.399* & 1383.73 & 654.07 & 271.37 \\
\hline Kosta Rika & -152.146 & 1146.87 & 445.420 & 125.620 & $469.717^{*}$ & 749.871 & 595.54 & 188.52 \\
\hline Ekvador & 19.724 & 1177.40 & 205.892 & 114.087 & $747.420^{* *}$ & 1026.37 & 389.10 & 242.81 \\
\hline El Salvador & -5.783 & 417.385 & 187.062 & 92.924 & -3641.80 & 1043.25 & 405.87 & 238.92 \\
\hline Honduras & -324.332 & 4580.29 & 324.766 & 65.113 & $93777.7^{* * *}$ & 662.507 & 345.08 & 224.74 \\
\hline Pakistan & -14.240 & 1387.88 & 197.183 & 72.257 & $594.914^{* *}$ & 7717.74 & 761.97 & 222.22 \\
\hline Paraguay & 14.150 & 304.771 & 132.008 & 91.529 & $655.358^{* *}$ & 8140.20 & 633.25 & 346.09 \\
\hline Peru & 30.661 & 4655.40 & 434.187 & 175.354 & 501.924* & 2717.17 & 745.41 & 274.67 \\
\hline Filipinler & 23.402 & 1684.53 & 391.481 & 90.063 & $607.497^{* *}$ & 1761.31 & 541.85 & 221.72 \\
\hline Romanya & -476.068 & 14855.8 & 779.541 & 231.948 & $749.035^{*}$ & 2631.91 & 1432.9 & 267.34 \\
\hline Ukrayna & 2.815 & 1434.74 & 131.208 & 55.504 & 25.016 & 1248.91 & 499.08 & 179.47 \\
\hline
\end{tabular}

Not: *, **, ***; \%10, \%5 ve \%1 düzeyinde anlamlılığı ifade etmektedir. Kritik değerler 1000 boostrap döngüsü ile elde edilmiştir.

Elde edilen bulgulara göre işgücüne katılım oranı ile kamu istihdamı arasında Arjantin ve Kolombiya'da çift yönlü nedensellik söz konusu iken; Bolivya, Kosta Rika, Ekvador, Honduras, Pakistan, Paraguay, Peru, Filipinler ve Romanya'da kamu istihdamından işgücü katılım oranına doğru tek yönlü nedensellik ilişkisi vardır.

\section{SONUÇ VE DEĞERLENDİRME}

Küreselleşmenin ulusal ekonomiler üzerinde yarattığı etkiler, verimsiz düzenlemelerin azaltılması ve kamu harcamalarının kısılması gibi politikaları içeren verimlilik hipotezi ile dışa açıklıkla birlikte ülke ekonomilerinin küresel ekonomide yaşanacak olumsuzluklardan daha kolay etkileneceğini, dolayısıyla kamu harcamalarının artacağını 
ifade eden telafi hipotezi çerçevesinde ele alınmaktadır.

Küreselleşmenin yol açtığı işsizlik gibi en önemli makroekonomik problem karşısında, kamu istihdamının nasıl etkilendiği toplam kamu harcamalarından ayrı olarak ele alınmayı gerektirmektedir. $\mathrm{Bu}$ hususlar çerçevesinde Dünya Bankası sınıflandırmasına göre orta gelirli olarak nitelendirilen 14 ülkede (Arjantin, Bolivya, Brezilya, Kolombiya, Kosta Rika, Ekvador, El Salvador, Honduras, Pakistan, Paraguay, Peru, Filipinler, Romanya ve Ukrayna) 2000-2014 dönemi verileriyle küreselleşmenin kamu sektörü istihdamına etkisi incelenmiştir. Yapılan analizin ilk aşamasında AMG yöntemiyle katsayı tahmin edilmiş, ikinci aşamada ise ülke özelinde değişkenler arasındaki nedensellik ilişkisini tespit etmeye imkân tanıyan Kónya (2006) panel bootstrap nedensellik testi uygulanmıştır.

Değişkenler arasındaki uzun dönemli ilişkiyi gösteren bulgular, tüm panel grubu için küreselleşmenin kamu istihdamiyla negatif ilișkili olduğunu göstermektedir. Bu bulgular telafi hipotezine karşılık, verimlilik hipotezini destekler niteliktedir. Ülke özelindeki sonuçlar incelendiğinde El Salvador, Peru, Filipinler ve Ukrayna'da küreselleșmenin kamu istihdamını negatif yönde etkilediği bulgusuna ulaşılmıştır. Kontrol değişkenleri olan kişi başı milli gelir ve ișgücüne katılım oranının kamu istihdamı üzerindeki etkisi de tüm panel grubunda negatif çıkmıştır. Ülke özelinde ise ekonomik büyümenin, kamu istihdamını Arjantin, Bolivya, Kosta Rika ve Romanya'da negatif; Peru'da pozitif yönde etkilediği görülmektedir. İşgücüne katılım oranının Bolivya, Brezilya, Kolombiya, Ekvador, Honduras ve Romanya'da kamu istihdamını negatif, Kosta Rika ve Peru'da ise pozitif yönde etkilediği tespit edilmiştir.

Değişkenler arasında nedensellik ilişkisine bakıldığında Bolivya, Brezilya, Honduras, Pakistan ve Peru'da küreselleşmeden kamu istihdamına doğru tek yönlü nedensellik ilişkisi söz konusudur. Kamu istihdamı ve ekonomik büyüme arasındaki nedensellik testi bulguları
Ekvador, El Salvador, Honduras ve Paraguay'da çift yönlü; Bolivya, Brezilya ve Romanya'da ekonomik büyümeden kamu istihdamına; Arjantin ve Kosta Rika'da ise kamu istihdamından ekonomik büyümeye doğru tek yönlü ilişkinin varlığını göstermektedir. Son olarak işgücüne katılım oranı ile kamu istihdamı arasındaki nedensellik ilişkisi Arjantin ve Kolombiya'da çift yönlü, Bolivya, Kosta Rika, Ekvador, Honduras, Pakistan, Paraguay, Peru, Filipinler ve Romanya'da kamu istihdamından işgücüne katılım oranına doğru tek yönlüdür. İşgücüne katılım oranından kamu istihdamına doğru ise hiçbir nedensellik ilişkisi tespit edilememiştir.

Sonuçlardan belirgin bir biçimde görüldüğü gibi orta gelirli ülkelerde dışa açıklık kamu istihdamını azaltmaktadır. Bu sonuçlar Garrett ve Mitchell (2001), Dreher vd. (2008b), Ram (2009) ve Gözgör vd. (2019)'nin çalışmalarıyla paralellik göstermektedir. Küreselleșmenin bu ülkelerde kamu istihdamı yoluyla kamu büyüklügünü negatif etkilemesi, esasen politik iktisat bağlamında değerlendirilebilecektir. Söz konusu ülke grubunun ekonomik ve politik yapıları incelendiğine ağırlıklı olarak Latin Amerika ve Asya ülkelerinden oluşmaktadır (Romanya ve Ukrayna bunların dişında kalmasına rağmen ekonomik ve politik istikrarsızlık sıklıkla yaşanmaktadır). Bu ülkelerin ortak özelliği, siyasi rejim krizleri ve ekonomik dar boğazların sıklıkla yaşandığı ülkeler olmalarıdır. Bu tip krizler, kamu sektörünün verimliliğini olumsuz etkilediği gibi kamu kaynaklarının bürokratik faaliyetler ve politik nedenlerle aşındırılmasına yol açarak vatandaşların devlete olan bakış açılarının değişmesine de neden olmaktadır. Şüphesiz küreselleşmenin yol açtığı istikrarsızlıklar nedeniyle ekonomik krizler yaşanmaktadır. Esasen kurumsal açıdan önemli zafiyetleri olan ülkelerde, uluslararası entegrasyonla birlikte bahsedilen kırılganlıklar daha da artmaktadır; fakat yaşanan bu kırılganlıklar kamunun düzenleyici işlevinin devreye girmesine yol açmamaktadır. 
Polterovich ve Popov (2005)'un vurguladığ gibi hukukun üstünlüğünün zaylf olduğu ülkelerde devletin kurumsal kapasitesinin zayıflaması, kamu gelirlerinin ve harcamalarının yavaş büyümesi ve kamusal düzenlemelerin kaynaklanmaktadır. Diğer yandan bu ülkelerde kurumların aşınması ekonomik büyümeyi de negatif etkilemektedir. Dolayısıyla yapılan ampirik analiz sonucunda elde edilen bulgular seçilen ülkeler için verimlilik hipotezinin geçerli olduğunu yansıtmaktadır.

\section{KAYNAKÇA}

Abounoori, E. ve Ghaderi, S. (2011). The Effect of Trade and Financial-Openness on Government Size: A Case Study for MENA. International Research Journal of Applied and Basic Sciences, 2(5), 170-174.

Aytaç, D. (2018). Küreselleşme, İşsizlik ve Kamu İstihdamı İlişkisi. Maliye Dergisi, 174, 131-153.

Benarroch, M. ve Pandey, M. (2012). The Relationship Between Trade Openness and Government Size: Does Disaggregating Government Expenditure Matter?. Journal of Macroeconomics, 34, 239-252.

Breusch, T. S. ve Pagan A. R. (1980). The Lagrange Multiplier Test and Its Applications to Model Specification in Econometrics. The Review of Economic Studies, 47(1), 239-253.

Busemeyer, M. R. (2009). From Myth to Reality: Globalisation and Public Spending in OECD Countries Revisited. European Journal of Political Research, 48, 455-482.

Cameron, D. R. (1978). The Expansion of the Public Economy: A Comparative Analysis. The American Political Science Review, 72(4), 1243-1261.

Cengiz O. ve Manga M. (2020). Küreselleşme ve Kamu Harcamaları Bileșenleri Arasındaki İlişki: AB Ülkeleri Örneği. Alanya Akademik Bakış Dergisi, 4(3), 807-819.

Davidson, C., Martin, L. ve Matusz, S. (1999). Trade and Search Generated Unemployment. Journal of International Economics, 48, 271299.
Dreher, A. (2006). Does Globalization Affect Growth? Evidence from a New Index of Globalization. Applied Economics, 38(10), 1091-1110.

Dreher, A., Gaston, N. ve Martens, P. (2008a). Measuring Globalisation-Gauging Its Consequences. New York: Springer.

Dreher, A., Sturm, J. E. ve Ursprung, H. W. (2008b). The Impact of Globalization on the Composition of Government Expenditures: Evidence from Panel Data. Public Choice, 134(3-4), 263-292.

Eberhardt, M. ve Bond, S. (2009). Cross-Section Dependence in Nonstationary Panel Models: A Novel Estimator. MPRA Paper No. 17692.

Epifani, P. ve Gancia, G. (2009). Openness, Government Size and the Terms of Trade. Review of Economic Studies, 76(2), 629-668.

Garen, J. ve Trask, K. (2005). Do More Open Economies Have Bigger Governments? Another Look. Journal of Development Economics, 77, 533- 551.

Garrett, G. ve Mitchell, D. (2001). Globalization, Government Spending and Taxation in the OECD. European Journal of Political Research, 39, 145-177.

Garrett, G. (2001). Globalization and Government Spending Around the World. Studies in Comparative International Development, 35(4), 3-29.

Gözgör, G., Bilgin, M. H. ve Zimmermann, K. F. (2019). Public Employment Decline in Developing Countries in the 21st Century: The Role of Globalization. Global Labor Organization (GLO), GLO Discussion Paper, No. 326. 
Gygli, S., Haelg, F., Potrafke, N. ve Sturm, J. E. (2019). The KOF Globalisation Index-Revisited. The Review of International Organizations, 14, 543-574.

Ibrahim, T. M. (2015). The Causal Link between Trade Openness and Government Size: Evidence from the Five Largest Economies in Africa. International Journal of Business and Economic Sciences Applied Research, 8(1), 121-136.

Karakurt, B. (2011). Washington Konsensüsü'nden Küresel Mali Krize Mali Disiplin ve Türkiye'deki Gelişmeler. Atatürk Üniversitesi İktisadi ve İdari Bilimler Dergisi, 25(1), 31-53.

Kónya, L. (2006). Exports and Growth: Granger Causality Analysis on OECD Countries with a Panel Data Approach. Economic Modelling, 23(6), 978-992.

Liberati, P. (2013). Government Size and Trade Openness: Some Additional Insights. Munich Personal RePEc Archive (MPRA), 1-9.

Pesaran, M. H. ve Smith, R. (1995). Estimating Long-Run Relationships from Dynamic Heterogeneous Panels. Journal of Econometrics, 68(1), 79-113.

Pesaran, M. H. ve Yamagata, T. (2008). Testing Slope Homogeneity in Large Panels. Journal of Econometrics, 142(1), 50-93.

Pesaran, M. H. (2004). General Diagnostic Tests for Cross Section Dependence in Panels. CESifo Working Paper Series No. 1229; IZA Discussion Paper No. 1240.

Pesaran, M. H. (2007). A Simple Panel Unit Root Test in the Presence of Cross-Section Dependence. Journal of Applied Econometrics, 22(2), 265-312.

Pesaran, M. H., Ullah, A. ve Yamagata, T. (2008). A Bias-Adjusted LM test of Error Cross-Section Independence. The Econometrics Journal, 11(1), 105-127.

Polterovich, V. ve Popov, V. (2005). Democracy and Growth Reconsidered: Why Economic Performance of New Democracies is not
Encouraging. Munich Personal RePEc Archive (MPRA), 1-34.

Ram, R. (2009). Openness, Country Size, and Government Size: Additional Evidence from a Large Cross-Country Panel. Journal of Public Economics, 93, 213-218.

Rama, M. (2003). Globalization and the Labor Market. The World Bank Research Observer, 18(2), 159-186.

Rodrik, D. (1996). Why Do More Open Economies Have Bigger Governments?. NBER Working Paper Series, Working Paper 5537, 127.

Rodrik, D. (2000). What Drives Public Employment in Developing Countries?. Review of Development Economics, 4(3), 229-243.

Schulze, G. G. ve Ursprung, H. W. (1999). Globalisation of the Economy and the Nation State. The World Economy, 22, 295-352.

Shahbaz, M., Rehman, H. U. ve Amir, N. (2010). The Impact of Trade and Financial-Openness on Government Size: A Case Study of Pakistan. Journal of Quality and Technology Management, 6(1), 105-118.

Shelton, C. A. (2007). The Size and Composition of Government Expenditure. Journal of Public Economics, 91, 2230-2260.

Spence, M. (2011). The Impact of Globalization on Income and Employment. Foreign Affairs, 90(4), 28-41.

Swamy, P. A. V. B. (1970). Efficient Inference in a Random Coefficient Regression Model. Econometrica: Journal of the Econometric Society, 311-323.

Şenses, F. (2004). Neoliberal Küreselleşme Kalkınma için Bir Fırsat mı, Engel mi?. ERC Working Paper in Economic 04/09, 1-27.

Şenses, F. (2010). Gelişme İktisadı ve İktisadi Gelişme-Nereden Nereye?. (5. Baskı). F. Şenses (Derl. ve Yay. Haz.), (Çev. S. Öztürk), Kalkınma İktisadı: Yükselişi ve Gerilemesi içinde (93-128. ss.). İstanbul: İletişim Yayınları. 
Tanzi, V. (2000). Globalization and the Future of Social Protection. IMF Working Paper, $\mathrm{WP} / 00 / 12,1-22$.

Tanzi, V. (2004). Globalization, Social Protection and Public Finance. Politiche Pubbliche, Sviluppo E Crescita, 1-35.

Tatoğlu, F. Y. (2017). Panel Zaman Serileri Analizi. İstanbul: Beta Yayınları.

World Bank (2018). The Worldwide Bureaucracy Indicators (WWBI) Dataset. Washington, D.C.: World Bank.

$\mathrm{Wu}, \mathrm{A}$. M. ve Lin, M. (2010). Determinants of Government Size: Evidence from China. Munich Personal RePEc Archive (MPRA), 1-26. 